\title{
Recurrent genital tract infection: a result of induced immunosuppression?
}

\author{
C SONNEX
}

From the Academic Department of Genitourinary Medicine, University College and Middlesex Hospital, School of Medicine, The Middlesex Hospital, London, UK

Many of the diseases commonly encountered in clinical practice may be considered as "recurrent", there being episodes of disease activity followed by variable periods of quiescence or low-grade activity. Although the aetiology of many of these conditions is unknown (for example, rheumatoid arthritis, ulcerative colitis, multiple sclerosis), certain infectious diseases are well known for their ability to recur. Interestingly, the genital tract appears particularly prone to recurrent disease. For example, true recurrence rather than reinfection has been well documented for herpes simplex virus (HSV) and human papillomavirus infection, candidiasis and nongonococcal urethritis. For the majority of patients recurrences are infrequent and pose few problems. However, a significant minority suffer frequent recurrences and experience severe physical and psychological morbidity.

This article reviews various studies which have attempted to examine the immunopathogenesis of recurrent genital tract infection or which have suggested possible mechanisms to account for disease recurrence. Before detailing the various infections, however, it is important to note that the immune mechanisms operating at mucosal sites are somewhat different from those providing systemic immunity. Mucosal antibody secretion involves a complex system in which IgA predominates. The IgA in genital secretions (secretory $\operatorname{IgA}$ ) is different from the $\operatorname{IgA}$ found in serum and is composed of a 10-S dimer, $J$ chain, and a secretory component. The complexity of mucosal humoral immunity has been well reviewed by $\mathrm{McNabb}$ and Tomasi. ${ }^{1}$ Mucosal cell-mediated immunity also exhibits certain unique characteristics. For example, the predominance of suppressor/ cytotoxic $\mathrm{T}$ lymphocytes in the genital tract contrasts with the pattern in lymphoid tissue where T-helper/ inducer lymphocytes outnumber suppressor cells. ${ }^{23}$

\footnotetext{
Address for reprint requests: Dr C Sonnex, Academic Department of Genitourinary Medicine, The Middlesex Hospital, London WIN 8AA, UK.
}

Accepted for publication 8 September 1989

\section{GENITAL HER PES}

Recurrent episodes of genital herpes are reported by $55 \%$ of patients after primary genital HSV type-1 infection and $88 \%$ following HSV type- 2 infection. ${ }^{4}$ Although the mean recurrence rate of genital HSV type- 2 infection has been reported as 0.33 per month, a small proportion of infected individuals exhibit a much higher frequency of recurrences. Although immunocompromised patients, such as those with haematological malignancies, organ transplants or those infected with human immunodeficiency virus (HIV), may suffer frequent, prolonged and often severe recurrences, the majority of patients with frequently recurrent herpes appear immunocompetent. However, a more detailed analysis of their immune responses often demonstrates certain abnormalities. For example, several studies have reported that lymphocytes from these individuals fail to elaborate lymphokines in response to HSV antigen as compared with individuals with well controlled latent infection. $^{6-8}$ This defect appears specific for herpes as responses to other antigens may be normal. Sheridan et al found that virus specific leucocyte migrationinhibition factor (LIF) production was impaired during episodes of recurrence and returned to normal during convalescence. ${ }^{9}$ This inhibition of LIF production correlated with a significant increase in the proportion of $\mathrm{CD} 8+$ and lymphocytes with antiHLA DR surface markers. Similarly, work from the guinea-pig model of recurrent HSV-2 has shown that "suppressor" cells may be found in the spleen during recrudescence but not quiescence nor in animals without a history of recurrent disease. ${ }^{10}$ These cells were able to suppress the induction of specific lymphoproliferative responses in vitro. Two functionally distinct suppressor $T$ cell populations have been identified in the mouse following injection of HSV infected cell sonicates. " 12 One acts on the induction of delayed hypersensitivity $(\mathrm{DH})$ responses (Lyt $1+2-$ and $\mathrm{IJ}+$ ) and the other population suppresses already established DH responses (Lyt $1-2+, \mathrm{IJ}+$ ). The suppressor $\mathrm{T}$ cell response is herpes type specific ${ }^{13}$ and appears, in addition, to be specific for $\mathrm{DH}$ responses. ${ }^{14}$ 
This latter feature has been termed "split tolerance" by Nash et al since cytotoxic $T$ cells and anti-herpes antibodies are induced thus providing immunity to reinfection. ${ }^{14}$ Horohov et al have more recently suggested that suppressor cell induction may require the interaction of at least three different $T$ cell populations. ${ }^{15}$ These included cells expressing the Lyt $2+$, the Lyt $1+$ and the $I J$ antigens. The interaction of these cells also involve the production of soluble suppressor factors. Horohov et al identified a 68,500 dalton HSV-specific suppressor factor in supernatants from HSV-1 stimulated mouse splenocytes. ${ }^{16}$ This contrasts with the 115,000 dalton suppressor factor (SF) consisting of two disulphide-bound proteins recently described by Aurelian et al. ${ }^{17} \mathrm{HSV}-\mathrm{SF}$ is thought to induce Lyt $2+$ suppressor effector cells which respond by producing non-specific suppressor factors which act as the ultimate suppressors. ${ }^{18} \mathrm{~A}$ small dialysable factor (molecular weight 8,200 dalton) which inhibits both LIF activity and interferon mediated enhancement of natural killer activity has also been recently described. ${ }^{1920}$ Interestingly, treatment of recrudescent mononuclear cells with indomethacin restored LIF activity. Although suggestive of a prostaglandin mediated inhibition further analysis has failed to document prostaglandin involvement.

\section{VAGINAL CANDIDIASIS}

Approximately three quarters of all adult women suffer at least one attack of candida vaginitis ${ }^{21}$ and $45 \%$ have more than one episode of infection. ${ }^{22} \mathrm{~A}$ small proportion of women suffer frequent recurrences and although not life-threatening, the symptoms can be debilitating.

The importance of the cell mediated response in controlling candida infection is well demonstrated by the severe mucocutaneous disease occurring in patients with defective cell mediated immunity such as DiGeorge's syndrome, chronic mucocutaneous candidiasis, haematological malignancy or HIV infection. Although these experiments of nature aid our understanding of immune responses, much of our knowledge of the immunology of candidiasis has resulted from animal models. In mice, a component of the candida cell has been shown to induce a suppressor B lymphocyte population which in turn depresses $\mathrm{T}$ cell activity. ${ }^{23}$ More recently, the glycoprotein of $C$ albicans cell walls was found to suppress normal cellular immune responses to itself while at the same time potentiating specific antibody production..$^{24}$ The suppressive effect was highly antigen specific. The induction of suppressor B-lymphocytes in vitro by formalin killed $C$ albicans has also been recently reported. ${ }^{25}$ Work with human lymphocyte cultures has documented the appearance of suppressor cells following stimulation by candida extracts, including purified polysaccharide (MPPS). ${ }^{26}$ In addition, MMPS activated human T cells have been found to produce a non-specific inhibitor of interleukin-1 (IL-1) production ${ }^{28}$ This is of some importance since IL-1, produced by macrophages and certain other cells, is a prime activator of antigen primed $T$ cells which in turn produce interleukin-2 (IL-2) and other lymphokines. ${ }^{29}$ IL-2 plays a key role in the proliferation of activated T cells. ${ }^{30}$ It should be emphasised, however, that the relevance of these studies to localised infection, such as vaginal candidiasis, is at present uncertain. Studies examining the immunopathogenesis of recurrent vaginal candidiasis are somewhat limited, Hobbs et al reported a reduced in vitro $T$ cell proliferative response to candida extract in 15 of 23 women with recurrent candida vaginitis. ${ }^{31}$ Similarly, Syverson et al observed a lack of cellular immune response to candida antigens in women with chronic candida vaginitis. ${ }^{32}$ Witkin et al have more recently reported that some women with recurrent candidiasis produce candida-specific suppressor lymphocytes (unspecified surface markers) and a soluble factor which blocks lymphocyte blast formation to candida. ${ }^{33} \mathrm{~A}$ follow-up to this study found that patients lymphocytes became fully responsive to candida when co-cultured with control macrophages or patient macrophages plus ibuprofen. ${ }^{34}$ Patient macrophages incubated with candida appeared to produce an excess of prostaglandin sufficient to inhibit the lymphocyte proliferative response to candida antigen. The collaboration between macrophages/monocytes and regulatory $\mathrm{T}$ cells in the initial induction of suppressor $\mathrm{T}$ cells is well documented. ${ }^{35}$ Moreover, the monocyte-mediated suppression of $T$ and $B$ lymphocyte proliferation and $B$ cell maturation appears to involve the activity of prostaglandin E2 on T lymphocytes ${ }^{36-38}$

\section{CONDYLOMATA ACUMINATA}

A proportion of patients with genital warts have lesions which are either resistant to treatment or frequently recur following treatment. A small number of studies have suggested that impaired cell mediated immunity may be responsible. Seski et al reported that women with recalcitrant genital warts and vulval intraepithelial neoplasia produced abnormal lymphocyte transformation responses to several mitogens. ${ }^{390}$ Impaired delayed hypersensitivity, assessed by leucocyte migration inhibition and tuberculin and dinitrochlorobenzene skin tests, has also been reported in patients with genital warts of long duration. ${ }^{41} \mathrm{~A}$ study of patients with "genital neoplasia-papilloma syndrome" (HPV-associated lesions in multiple genital sites with at least one intraepithelial or invasive squamous neoplasia) has documented decreased lymphocyte proliferative responses to mitogens and 
increased suppressor-cytotoxic T-cells (CD8 +) compared with control subjects. ${ }^{42}$ Interestingly, over $50 \%$ of the patients studied had a history of recurrent candida infections. Immunosuppressed patients with defective cell mediated immunity are particularly prone to develop multiple intractable genital warts, ${ }^{43}$ again emphasising the importance of the cell mediated immune response.

\section{CHLAMYDIA TRACHOMATIS}

Chlamydia trachomatis causes approximately $30-50 \%$ of non-gonococcal urethritis ${ }^{44}$ and recurrence or persistence of symptoms post-treatment has been reported to occur in $19 \%$ of cases. ${ }^{45}$ Chlamydiae are potent inducers of B lymphocyte proliferation. ${ }^{4647}$ Whereas relatively small numbers of organisms generate this response, larger numbers of chlamydia fail to stimulate B cell proliferation but induce potent suppressor T-lymphocyte activity. ${ }^{48}$ Thus during early infection B cell proliferation is thought to occur. Subsequently, infected cells release organisms which result in stimulation of suppressor $T$ cells thereby leading to a down-regulation of the immune response. It should be emphasised that this hypothetical model may not apply to localised infection of the male urethra. Further studies are required to determine the relevance of suppressor cell activation in recurrent urethritis.

\section{Conclusion}

The genital infections discussed in this article all share the ability to produce frequent recurrences in certain individuals. Examining the immunological mechanisms underlying these recurrences reveals cellmediated immunosuppression as a common feature. This immunosuppression may be antigen specific or non-specific and involves activated suppressor cells and/or the production of soluble inhibitory factors. Suppressor systems are known to regulate the immune responses to a variety of infectious agents ${ }^{4-55}$ and are the subject of recent reviews. ${ }^{5657} \mathrm{~A}$ general feature of the suppressor T-cell system is the involvement of major histocompatibility complex genes in the induction and expression of suppressor T-cell activity. A relationship has been documented between HLA-B15 antigen and low in-vitro and in-vivo responsiveness to candida antigen ${ }^{58}$ and between HLA-Al and recurrent circumoral herpes infection. ${ }^{59}$ Information regarding the HLA status of patients with recurrent genital tract infection is lacking. Further work is required to elucidate fully the role of suppressor cells and their products in the pathogenesis of recurrent genital tract infection in humans. This is of some importance since they could provide a target for treatment aimed at breaking the disease cycle. In addition, the reports of prostaglandin E2 induced immunosuppression and the abrogation of antigen-specific suppression of mononuclear cell proliferation by prostaglandin inhibitors may also provide a basis for therapy. Preliminary results suggest that some women with recurrent candidiasis benefit from taking ibuprofen. ${ }^{34}$ Although this particular medication had no effect in treating clinical recurrences of genital herpes ${ }^{60}$ the use of ibuprofen, or a similar drug, as a prophylactic agent has not been assessed.

There are obviously many avenues along which future research could proceed. Our knowledge of local immunity within the genital tract is slowly growing and the concept of "genital tract associated lymphoid tissues", comparable to the skin and gut-associated lymphoid tissues, may soon be appreciated. The role of suppression of local immunity (for example, IgA responses), as suggested by Nash, ${ }^{6}$ is one particular area which merits investigation. An improved understanding of the immunopathogenesis of recurrent genital tract infection will hopefully enable us to manage these debilitating conditions rather more effectively.

I thank Dr Q Sattentau, Dr C Loveday and Professor J H L Playfair for their constructive advice and criticism.

\section{References}

$1 \mathrm{McNabb}$ PC, Tomasi TB. Host defence mechanisms at mucosal surfaces. Ann Rev Microbiol 1981;35:477-96.

2 Morris HHB, Gatter KC, Stein H, Mason DY. Langerhans' cells in human cervical epithelium: an immunohistological study. Br J Obstet Gynaecol 1983;90:400-11.

3 El-Demiry MIM, Hargreave TB, Busuttil A, James K, Ritchie AWS, Chisholm GD. Lymphocyte sub-populations in the male genital tract. Br J Urol 1985;57:769-74.

4 Corey L, Adams HG, Brown ZA, Holmes KK. Genital herpes simplex virus infections: clinical manifestations, course, and complications. Ann Int Med 1983;98:958-72.

5 Lafferty WE, Coombs RW, Benedetti J, Critchlow C, Corey L. Recurrences after oral and genital herpes simplex virus infection. N Engl J Med 1987;316:1444-9.

6 Wilton JMA, Ivanyi L, Lehner T. Cell mediated immunity in herpes virus hominius infections. Br Med J 1972;1:723-6.

7 Shillitoe EJ, Wilton JMA, Lehner T. Sequential changes in cellmediated immune responses to herpes simplex virus after recurrent herpetic infections in humans. Infect Immun 1977; 18:130-7.

8 O'Reilly RJ, Chibbaro A, Anger E, Lopez C. Cell mediated immune responses in patients with recurrent herpes simplex infections II. Infection-associated deficiency of lymphokine production in patients with recurrent herpes labialis or herpes progenitalis. J Immunol 1977;118:1095-1 102.

9 Sheridan JF, Donnenberg AD, Aurelian L, Elpern DJ. Immunity to herpes simplex virus type 2 IV. Impaired lymphokine production during recrudescence correlates with an imbalance in T lymphocyte subsets. J Immunol 1982;129:326-31.

10 Iwasaka T, Sheridan JF, Aurelian L. Immunity to herpes simplex virus type 2: recurrent lesions are associated with the induction of suppressor cell and soluble suppressor factors. Infect Immun 1983;42:955-64.

11 Nash AA, Gell PGH, Wildy P. Tolerance and immunity in mice infected with herpes simplex virus: simultaneous induction of protective immunity and tolerance to delayed-type hypersensitivity. Immunology 1981;43:153-9.

12 Shrier RD, Pizer LI, Moorhead JW. Tolerance and suppression of immunity to herpes simplex virus: different presentations of antigens induce different types of suppressor cells. Infect Immun 1983;40:514-22.

13 Nash AA, Phelan P, Gell PGH, Wildy P. Tolerance and immunity in mice infected with herpes simplex virus: studies on the mechanism of tolerance to delayed-type hypersensitivity. 
Immunology 1981;43:363-9.

14 Nash AA, Ashford NPN. Split T-cell tolerance in herpes simplex virus infected mice and its implication for anti-viral immunity. Immunology 1982;48:761-7.

15 Horohov DW, Moore RN, Rouse BT. Regulation of herpes simplex virus-specific lymphoproliferation by suppressor cells. J Virol 1985;56:1-6.

16 Horohov DW, Wyckoff III JH, Moore RN, Rouse BT. Regulation of herpes simplex virus-specific cell-mediated immunity by a specific suppressor factor. J Virol 1986;58:331-8.

17 Aurelian L, Yasumoto S, Smith CC. Antigen-specific immunesuppressor factor in herpes simplex virus type 2 infections of UV B-irradiated mice. $J$ Virol 1988;62:2520-4.

18 Malkovsky M, Asherson GL, Chandler P, Colizzi V, Watkins MC, Zembala $M$. Non specific inhibition of DNA synthesis elaborated by $\mathrm{T}$ acceptor cells. I. Specific hapten and I-J-driven liberation of an inhibitor of cell proliferation by Lyt 1-2+ cyclophosphamide sensitive $T$ acceptor cells armed with a product of Lyt 1+2+ cells. J Immunol 1983;130:785-90.

19 Sheridan JF, Beck M, Aurelian L, Radowsky M. Immunity to herpes simplex virus: virus reactivation modulates lymphokine activity. $J$ Infect Dis 1985;152:449-56.

20 Sheridan JF, Beck M, Smith CC, Aurelian L. Reactivation of herpes simplex virus is associated with production of a low molecular weight factor that inhibits lymphokine activity in vitro. J Immunol 1987;138:1234-9.

21 Berg AO, Heidrich FE, Fihn SD. Establishing the cause of symptoms in women in a family practice. $J A M A$ 1984;251: 620-5.

22 Hurley R. Inveterate vaginal thrush. Practitioner 1975;215:753-6.

23 Rivas V, Rogers TJ. Studies on the cellular nature of Candida albicans-induced suppression. J Immunol 1983;130:376-9.

24 Carrow EW, Domer JE. Immunoregulation in experimental murine candidiasis: specific suppression induced by Candida albicans cell wall glycoprotein. Infect Immun 1985;49:172-81.

25 Cuff CF, Rogers CM, Lamb BJ, Rogers TJ. Induction of suppressor cells in vitro by candida albicans. Cell Immunol 1986;100:47-56.

26 Borkowsky W, Valentine FT. The proliferative response of human lymphocytes to antigen is suppressed preferentially by lymphocytes precultured with the same antigen. $J$ Immunol 1979; 122:1867-73.

27 Piccolella E, Lombardi G, Morelli R. Generation of suppressor cells in the response of human lymphocytes to a polysaccharide from Candida albicans. J Immunol 1981;126:2151-5.

28 Lombardi G, Vismara D, Piccolella E, Colizzi V, Asherson GL. A non-specific inhibitor produced by Candida albicans activated $T$ cells impairs cell proliferation by inhibiting interleukin-1 production. Clin Exp Immunol 1985;60:303-10.

29 Mizel SB. Interleukin 1 and $T$ cell activation. Immunol Rev 1982;63:51-72.

30 Gillis S, Mochizuki DY, Conlon PJ, et al. Molecular characterisation of interleukin-2. Immunol Rev 1982;63:167-209.

31 Hobbs JR, Brigden D, Davidson F, Kahan M, Oates JK. Immunological aspects of candida vaginitis. Proc $R$ Soc Med 1977;70 (suppl 4):11-13.

32 Syverson RE, Buckley H, Gibian J, Ryan GM. Cellular and humoral immune status in women with chronic Candida vaginitis. Am J Obstet Gynecol 1979;134:624-7.

33 Witkin SS, Yu I-R, Ledger WJ. Inhibition of Candida albicansinduced lymphocyte proliferation by lymphocytes and sera from women with recurrent vaginitis. Am J Obstet Gynecol 1983;147:809-11.

34 Witkin SS, Hirsch J, Ledger WJ. A macrophage defect in women with recurrent Candida vaginitis and its reversal in vitro by prostaglandin inhibitors. Am J Obstet Gynecol 1986;155:790-5.

35 Eimasry MN, Fox EJ, Rich RR. Opposing immunoregulatory functions of CD8 + lymphocytes: a requirement for monocytes in suppressor cell induction. J Immunol 1986;137:2468-77.

36 Fischer A, Durandy A, Griscelli C. Role of prostaglandin E2 in the induction of non-specific lymphocyte suppressor activity. $J$ Immunol 1981;126:1452-5.

37 Rappaport RS, Dodge GR. Prostaglandin E inhibits the production of human interleukin 2. J Exp Med 1982;155:943-8.
38 Chouaib S, Chatenoud L, Klatzmann D, Fradelizi D. The mechanisms of inhibition of human IL-2 production II. PGE2 induction of suppressor T lymphocytes. J Immunol 1984; 132: $1851-7$

39 Seski JC, Reinhalter ER, Silva J. Abnormalities of lymphocyte transformations in women with condylomata acuminata. Obstet Gynecol 1978;51:188-92.

40 Seski JC, Reinhalter ER, Silva J. Abnormalities of lymphocyte transformations in women with intraepithelial carcinoma of the vulva. Obstet Gynecol 1978;52:334-6.

41 Avgerinou G, Georgala S, Theodoridis A, Vareltzdis A, Stratigos J. Reduction of cell mediated immunity in patients with genital warts of long duration. Genitourin Med 1986;62:396-8.

42 Carson LF, Twiggs LB, Fukushima M, Ostrow RS, Faras AJ, Okagaki T. Human genital papilloma infections: an evaluation of immunological competence in the genital neoplasiapapilloma syndrome. Am J Obstet Gynecol 1986;155:784-9.

43 Morison WL. Viral warts, herpes simplex and herpes zoster in patients with secondary immune deficiencies and neoplasms. $\mathrm{Br}$ J Dermatol 1975;92:625-30.

44 Bowie WR. Urethritis in males. In: Holmes KK, Mardh P-A Sparling PF, Wiesner PJ, Sexually transmitted diseases. New York: McGraw-Hill, 1984:638-50.

45 Bowie WR, Alexander ER, Stimson JB, Floyd JF, Holmes KK. Therapy for non-gonococcal urethritis. Ann Int Med 1981;95:306-11.

46 Bard J, Levitt D. Chlamydia trachomatis stimulates human peripheral blood B lymphocytes to proliferate and secrete polyclonal immunoglobulins in vitro. Infect Immun 1984;43: 84-92.

47 Levitt D, Danen R, Bard J. Both species of chlamydia and two biovars of Chlamydia trachomatis stimulate mouse B lymphocytes. J Immunol 1986;136:4249-54.

48 Levitt D, Corlett R. Patterns of immunoenhancement and suppression induced by Chlamydia trachomatis in vivo and in vitro. J Immunol 1988;140:273-6.

49 Schwab JH. Suppression of the immune response by microorganisms. Bacteriol Rev 1975;39:121-43.

50 Stobo JD, Paul S, Van Scoy RE, Hermans PE. Suppressor thymusderived lymphocytes in fungal infection. $J$ Clin Invest 1976; 57:319-28.

51 Rinaldo CR, Carney WP, Richter BS, Black PH, Hirsch MS Mechanism of immunosuppression in cytomegalovirus mononucleosis. J Infect Dis 1980;141:488-95.

52 Greene MI, Weiner HL. Delayed hypersensitivity in mice infected with reovirus, II. Induction of tolerance and suppressor T cells to viral specific gene products. J Immunol 1980;125:283-7.

53 Murphy JW, Moorhead JW. Regulation of cell-mediated immunity in cryptococcosis. I. Induction of specific afferent suppressor cells by cryptococcal antigen. $J$ Immunol 1982;128:276-83.

54 Doughty BL, Phillips SM. Delayed hypersensitivity granuloma formation and modulation around Schistosoma mansoni eggs in vitro. II. Regulatory T cell subsets. J Immunol 1982;128: $37-41$.

55 Petit J-C, Richard G, Albert B, Daguet G-L. Depression by Pseudomonas aeruginosa of two T-cell mediated responses, antiListeria immunity and delayed-type hypersensitivity to sheep erythrocytes. Infect Immun 1982;35:900-8.

56 Dorf ME, Benacerraf B. Suppressor cells and immunoregulation. Ann Rev Immunol 1984;2:127-58.

57 Gilbert KM, Hoffman MK. Suppressor B lymphocytes. Immunol Today 1983;4:253-5.

58 Nose Y, Komori K, Inouye H, Nomura K, Yamamura M, Tsuji $K$. Relationship between HLA-D and in vitro and in vivo responsiveness to candida antigen. Clin Exp Immunol 1980; 40:345-50.

59 Russell AS, Schlaut J. Association of HLA-A1 antigen and susceptibility to recurrent cold sores. Arch Dermatol 1977; 113:1721-2.

60 Milch PO, Monheit AG, Rochelson BL, Metz G, Baker DA. Failure of ibuprofen in treatment of herpes genitalis. Am J Obstet Gynecol 1986;155:399-400.

61 Nash AA. Tolerance and suppression in virus diseases. $\mathrm{Br}$ Med Bull 1985;41:41-5. 